\title{
Competition Between Weeds and Pepper in Southern Italy
}

\author{
Stella Lovelli*, Teodoro Di Tommaso, Mariana Amato, Maria Valerio, Michele Perniola \\ Crop System, Forestry and Environmental Sciences Department, University of Basilicata \\ Viale dell'Ateneo Lucano 10, 85100 Potenza, Italy
}

Received: 14 September 2009. Accepted: 12 January 2010.

\begin{abstract}
In arid areas drought conditions and warmer temperatures will alter the competitive balance between crops and some weed species. The objective of this study was to study water competition and its effect on canopy relationship of a C4 weed (pigweed) and a C3 weed (bindweed) towards a C3 crop (pepper) in a Mediterranean area. The experiment was carried out in 2008 in Matera, Southern Italy. Pigweed and bindweed were studied within a naturally occurring weed population in a bell pepper field where a rainfed treatment (V0) was compared to a full irrigated one (V100), the latter corresponding to the restoration of $100 \%$ of the maximum crop evapotranspiration, (ETc). Soil water content was measured periodically; leaf water potential, net assimilation rate (A), stomatal conductance (gs), transpiration rate (T), $\mathrm{Ci}$ (intercellular $\mathrm{CO}_{2}$ concentration) and $\mathrm{A} / \mathrm{Ci}$ curves were also determined on pigweed, bindweed and pepper leaves.

All gas exchange parameters differed between irrigated and rainfed treatments and between the three species. Water use efficiency was higher in pigweed than in pepper and bindweed. Between the considered weeds, pigweed competed for water with pepper significantly since, unlike bindweed, pigweed began to reduce stomatal conductance only when its leaf water potential achieved very negative values, lower than $-2.00 \mathrm{MPa}$. Unlike $\mathrm{C} 4 \mathrm{crops}$ already saturated for $\mathrm{CO}_{2}$, pigweed photosynthesis is not completely saturated for $\mathrm{CO}_{2}$. Consequently, since atmospheric $\mathrm{CO}_{2}$ is increasing, when pigweed is grown in mixed stands where competition occurs, it can further limit other slow-growing species, both crops and weeds.
\end{abstract}

Key-words: Pigweed, Amaranthus retroflexux L., Bindweed, Convolvulus arvensis L., leaf water potential, stomatal conductance, water use efficiency.

\section{Introduction}

Some authors (Bajaj et al., 1999) estimated that two-thirds of the potential yield of major crops are usually lost due to adverse growing environments. Moreover, currently weed control is one of the greatest costs for farmers. As known weeds interfere with crop growth and depress yield by competing for available resources (Zimdahl, 2004). In addition, future growing conditions for crops will be altered by climate change in several ways, including greater atmospheric $\left[\mathrm{CO}_{2}\right]$, higher temperature, altered timing and quantity of water availability, greater tropospheric $\left[\mathrm{O}_{3}\right]$ and altered incidence of pests, diseases and pollinator actions. In addition, most climate change scenarios predict a worldwide increase of arid areas throughout the world, including the Mediterranean basin (IPPC, 2001 and 2007).

In natural ecosystems where species with the C3 and C4 pathways contemporarily occur, the periods of their most active growth are temporally separated so that competition is little intense (Patterson, 1995). In the agroecosystem, the growth and competitive interactions of $\mathrm{C} 3$ and $\mathrm{C} 4$ crops and weeds are synchronized by the timing of crop sowing and by other management practices (Patterson, 1995).

In these last years with the certainty that Earth's climate is changing and that global warming seems to be inevitable, regardless of

\footnotetext{
* Corresponding Author: Tel.: +39 0971 205384; Fax: +39 0971 205378. E-mail address: stella.lovelli@unibas.it
} 
future gas emission reductions, it has become very important to identify potential vulnerabilities and adaptive responses in managed ecosystems (Howden et al., 2007).

Some authors (Tungate et al., 2007) underlined that warmer temperatures will alter the competitive balance between crops and weed species, intensifying weed pressures. Competition for water by weeds and effect of weed growth on yield is well recognized (French and Schultz, 1984b). Notwithstanding, field-based information on weed physiology is essential to achieve a better understanding of how changes in temperature may alter weed growth and competition relationships with crops.

Pigweed (Amaranthus retroflexus L.) is a summer annual invasive plant, widely distributed in Italy and in other areas of the world in cultivated lands. It is difficult to manage in agronomic crops because of prolonged germination period, relatively fast growth, high seed production and long-term seed viability. Some authors (Horak and Loughin, 2000, Lovelli et al., 2010) observed that pigweed is an increasingly aggressive weed in semiarid environments and that, in general, the control of Amaranthus species is becoming very difficult.

Field bindweed (Convolvulus arvensis L.) is a perennial weed in Europe and many agricultural areas of the world (Weaver and Riley, 1982). This weed has been described as the twelfth worst weed in the world (Holm et al., 1977). In agroecosystem bindweed reduces crop value through competition and by interfering with the harvest procedures (Pfirter at al., 1997). Moreover, field bindweed provides a breeding site for insects attacking adjacent crops (Tamaki et al., 1975). In some cases it serves as an alternative host for viruses which cause plant diseases (Holm et al., 1977). Bindweed control by both mechanical and chemical methods is very difficult because of its high regeneration ability
(Pfirter at al., 1997). It is possible to stop shoot growth and reduce the amount of root by repeating herbicide applications but, even after several years applications, the growth of some roots, which can allow further shoot development, remains (Timmons, 1949).

The objective of this study was to study water competition of a $\mathrm{C} 4$ weed (pigweed) and a C3 weed (bindweed) with a C3 crop (bell pepper) at canopy level, in a Mediterranean area.

\section{Materials and methods}

\section{Plant material and growth conditions}

The experiment was carried out in 2008 in Matera, Southern Italy $\left(40^{\circ} 00^{\prime} \mathrm{N}\right.$; $16^{\circ} 00^{\prime} \mathrm{E}$; $397 \mathrm{~m}$ a.s.l.) on a loam soil with a moderate chemical fertility. Soil moisture content was $24.2 \%$ at field capacity and $17.2 \%$ at the theoretical wilting point (determined in lab at -0.03 and -1.5 MPa respectively). Plots consisted of six $30 \mathrm{~m}$ rows, spaced $1 \mathrm{~m}$ apart. Soil tillage consisted of moldboard ploughing, disking and land levelling previous to crop planting. Bell pepper (Capsicum annuum L.) (cv. peppone) was transplanted on 19-05-08, $1 \mathrm{~m}$ x $0.4 \mathrm{~m}$ spaced and gradually harvested until 26/08/2008. During the trial $150 \mathrm{~kg} \mathrm{ha}^{-1}$ of $\mathrm{N}, 150 \mathrm{~kg} \mathrm{ha}^{-1}$ of $\mathrm{P}_{2} \mathrm{O}_{5}$ and $180 \mathrm{~kg} \mathrm{ha}^{-1}$ of $\mathrm{K}_{2} \mathrm{O}$ were applied. Naturally occurring weed populations were used in the experiments (Tab. 1).

\section{Experimental design}

Two different irrigation treatments, arranged in the field as a split-plot design with four replications, were compared: rainfed (V0) and fully irrigated (V100), where $100 \%$ of total crop evapotranspiration (ETc) was restored. Irrigation was applied when $40 \%$ of total available water was depleted according to the evapotraspirometric method of Doorenbos and Pruitt

Table 1. Densities of weeds observed on field at harvesting of pepper.

\begin{tabular}{lccc}
\hline Latin name & Common name & Density $\left(\right.$ plants $\left.\mathrm{m}^{-2}\right)$ \\
\hline & & $\mathrm{V} 0$ & $\mathrm{~V} 100$ \\
Amaranthus retroflexus L. & Pigweed & $3 \pm 0.2$ & $30 \pm 0.2$ \\
Convolvulus arvensis L. & Bindweed & $1 \pm 0.1$ & $15 \pm 3.0$ \\
Chenopodium album L. & Lamsquarters & $3 \pm 0.2$ & $6 \pm 1.2$ \\
Portulaca oleracea L. & Purslane & $22 \pm 0.6$ & $12 \pm 4.5$ \\
\hline
\end{tabular}

Values are means \pm standard error. 
(1977). ETc was calculated as ETc $=$ ETo $\mathrm{x}$ Kc where ETo (reference evapotraspiration) was calculated according to Hargreaves and Samani (1985):

$$
\begin{gathered}
\mathrm{ETo}=0.0023\left(\mathrm{~T}_{\text {mean }}+17.8\right) \\
\left(\mathrm{T}_{\max }-\mathrm{T}_{\min }\right)^{0.5} \mathrm{R}_{\mathrm{a}}
\end{gathered}
$$

where: $\mathrm{T}_{\text {mean }}, \mathrm{T}_{\text {max }} \mathrm{T}_{\text {min }}$ mean, maximum and minimum air temperature in ${ }^{\circ} \mathrm{C}$, respectively and $\mathrm{Ra}$ is the extraterrestrial solar radiation in $\mathrm{mm} \mathrm{d}^{-1}$ (tabulated value). Kc was the crop coefficient of bell pepper as reported by Allen et al., (1998), corrected for the specific environmental conditions, yielding $\mathrm{Kc}$ ini $=0.5 ; \mathrm{Kc}$ med $=1.15 ; \mathrm{Kc}$ end $=0.8$. Drip irrigation was used, with dripping wings placed on each row and "on line" drippers, spacing $20 \mathrm{~cm}$, with a $31 \mathrm{~h}^{-1} \mathrm{de}$ livery. Photosynthetic Active Radiation, max and $\min \mathrm{T}$, air humidity and wind speed were acquired every $10 \mathrm{~min}$ by a weather station placed in a meadow next to the plots, averaged and recorded every $30 \mathrm{~min}$ by a datalogger (Model Sky DataHog2, type SDL5400).

\section{Soil water status}

Soil water content was periodically measured during the experiment and at the moment of photosynthetic measurements by gravimetric method at $0-30 \mathrm{~cm}$ and $30-60 \mathrm{~cm}$ depth and expressed as soil water potential, after determining the soil water retention curve in the lab.

\section{Plant water status}

Leaf water potential $(\Psi)$ was measured on pigweed, bindweed and pepper plants 40 days after transplantation of bell pepper. Measurements were made on the youngest uppermost fully-expanded leaf of four representative plants per treatment, using pressure chamber technique (Scholander et al., 1965).

\section{Gas exchange analysis}

Instantaneous gas exchange measurements were made on pigweed, bindweed and pepper plants 40 days after transplantation of the main crop on the youngest uppermost fully-expanded leaf of four representative plants per treatment. Net assimilation rate (A), stomatal conductance (gs), transpiration rate $(\mathrm{T})$ and $\mathrm{Ci}$ (intercellular $\mathrm{CO}_{2}$ concentration) were simultaneously determined, using the youngest, fully expanded 40 days old leaf. These measurements were made on four plants for each treatments. A portable open - gas exchange system (Model LiCor-6400, Li Corporation, Lincoln, NE, USA) was used, incorporating infrared $\mathrm{CO}_{2}$ and water vapour analyzers and using a saturating red light source at a PPFD (Photosynthetic Photon Flux Density) of $1800 \mu \mathrm{mol} \mathrm{m} \mathrm{s}^{-1}$. The cuvette temperature was held at the mean air temperature at noon on the measurement day $\left(33^{\circ} \mathrm{C}\right)$ and the relative humidity within the cuvette was maintained at $20 \%$. Water use efficiency at the leaf level $\left(\mathrm{WUE}_{1}\right)$ was calculated as the ratio between assimilated $\mathrm{CO}_{2}$ and transpired $\mathrm{H}_{2} \mathrm{O}\left(\mu \mathrm{mol} \mathrm{CO}_{2}\right.$ $\mathrm{mmol}^{-1} \mathrm{H}_{2} \mathrm{O}$ ).

The response of $A$ to $C$ i was assessed only on irrigated plots (V100) by changing the concentration of $\mathrm{CO}_{2}$ entering the leaf chamber $\left(\mathrm{O}_{2}\right.$ was maintained at $\left.210 \mathrm{mmolmol}^{-1}\right)$. Three plants assayed over three consecutive days were used per treatment. Each sample consisted of one fully-expanded leaf of pigweed, bindweed and pepper plants from each plot. Measurements for the $A / C$ i response curve were carried out with a saturating red light source at a PPFD of $1800 \mu \mathrm{mol}$ $\mathrm{m}^{-2} \mathrm{~s}^{-1}$ and maintaining leaf temperature near to the air temperature in field on that day (33$34^{\circ} \mathrm{C}$ ). The $\mathrm{CO}_{2}$ concentration of the cuvette was initially maintained at $380 \mu \mathrm{mol} \mathrm{mol}{ }^{-1}$ for 5 min to stimulate stomatal opening, then reduced to $300,200,100,0$ and then increased to 100 , 200, 300, 400, 500, 700, 800, 900, 1200, $2000 \mu \mathrm{mol}$ $\mathrm{mol}^{-1}$ and gas exchange properties were logged after the system had achieved a predetermined stability point. Curve fitting software was used to analyze the $A / C$ i response curves using the following three component exponential function:

$$
A=a\left(1-e^{-b x}\right)+c
$$

where $A=$ steady-state assimilation rate and $x$ $=\mathrm{Ci}$ (intercellular $\mathrm{CO}_{2}$ concentration).

In interpreting the $\mathrm{CO}_{2}$ response of photosynthesis in pepper and pigweed (C3 plants) carboxylation efficiency $(K)$ was calculated as the initial slope of the curve by the following equation:

$$
K=A /(\mathrm{Cc}-\Gamma)
$$

by Farquhar and Sharkey 1982, where $A$ is the net assimilation rate at atmospheric $\mathrm{CO}_{2}, \mathrm{Cc}$ is the $\mathrm{CO}_{2}$ concentration inside the chloroplast 
(assumed to be equal to $\mathrm{Ci}$ ) and $\Gamma$ is the compensation point. By equation [2] the $A_{\max }$ (maximum assimilation rate) was calculated as $a+c$.

In interpreting the $\mathrm{CO}_{2}$ response of photosynthesis in pigweed, the model of $\mathrm{C} 4$ photosynthesis developed by Von Caemmerer and Furbank (1999) was used. By equation [2], the $A_{\text {sat }}\left(\mathrm{CO}_{2}\right.$ saturated rate) was calculated as $a+$ $c$. This last value is an indicator of the ribulose1,5-bisphosphate carboxylase/oxygenase activity (Rubisco activity), of the Phosphoenolpyruvate regeneration rate and electronic transport rate. The CE value, indicator of Phosphoenolpyruvate carboxylase (PEPC) activity was calculated as the slope at $\mathrm{A}=0$ (calculated as $\mathrm{b}[\mathrm{a}+\mathrm{c}]$ ).

\section{Statistical analysis}

The statistical design was a split-plot with four replications. Analysis of variance (ANOVA) was performed and mean discrimination was carried out according to the Duncan's Multiple Range Test. Significant differences were accepted at $\mathrm{P}$ $<0.05$ and $\mathrm{P}<0.01$ and represented by different letters. To compare $\mathrm{A} / \mathrm{Ci}$ curves we combined all the data sets to obtain a unique curve (combine model). Parameters of this unique curve were then compared with the specific model of each curve with the F-test according to the following equation:

$$
\frac{R S S_{c}-\sum R S S_{i}}{\frac{d f_{c}-\sum d f_{i}}{\sum R S S_{i}}}
$$

where $\mathrm{RSS}_{\mathrm{c}}=$ residual sum of square of the combine model; $\mathrm{RSS}_{\mathrm{i}}=$ residual sum of square of each curve; $\mathrm{df}_{\mathrm{c}}=$ residual degrees of freedom of the combine model; $\mathrm{df}_{\mathrm{i}}=$ residual degrees of freedom of each curve. All the analysis were carried out using the statistical package Sigma Plot 11.0 for Windows (USA).

\section{Results}

In the irrigated treatment the most present weeds at pepper harvesting were pigweed (Amaranthus retroflexux L., C4 plant) and bindweed (Convolvolus arvensis L., C3 plant). Other weeds also observed on the bell pepper
Table 2. Leaf water potential of pepper, pigweed and bindweed measured 40 days after pepper transplantation.

\begin{tabular}{|c|c|c|}
\hline & \multicolumn{2}{|c|}{ Leaf water potential $(\mathrm{MPa})$} \\
\hline & V0 & V100 \\
\hline Pepper & $-1,7 \pm 0.09$ & $-1,1 \pm 0.07$ \\
\hline Pigweed & $-2,4 \pm 0.04$ & $-1,7 \pm 0.04$ \\
\hline Bindweed & $-1,9 \pm 0.08$ & $-1,4 \pm 0.13$ \\
\hline
\end{tabular}

Values are means \pm standard error.

field were purslane (Portulaca oleracea L.) and common lambsquarters (Chenopodium album L.). In irrigated treatment pigweed prevailed, while in drought conditions purslane prevailed (Tab. 1).

A significant decrease in soil water potential was observed in rainfed conditions. At the moment of photosynthetic measurements, 40 days after transplantation of the main crop, the average soil water potential for the whole $0-60 \mathrm{~cm}$ depth soil volume was $-0.96 \mathrm{MPa}$ in V100 plots and -2.24 MPa in V0 plots. The average soil water status of -2.24 MPa reported in the V0 treatment corresponds to $0.74 \mathrm{MPa}$ below the theoretical wilting point. Consequently, highly significant differences in plant water status were found at noon among treatments (Tab. 2). The lower value was measured on pigweed in rainfed treatment, while the higher leaf water potential was measured on irrigated pepper, -2.4 and -1.1 MPa, respectively (Tab. 2).

All gas exchange parameters differed between irrigated and rainfed treatments and among the three species (Tab. 3). We observed a significant effect of drought conditions on photosynthetic rate of all three species. Of course, higher value of net assimilation, was recorded in pigweed, $37.6 \mu \mathrm{mol} \mathrm{m} \mathrm{m}^{-2} \mathrm{~s}^{-1}$ and 13.9 $\mu \mathrm{mol} \mathrm{m} \mathrm{m}^{-2} \mathrm{~s}^{-1}$ in V100 treatment and in V0 treatment, respectively (Tab. 3). Lower assimilation values were measured in bindweed, 3.0 and 1.1 $\mu \mathrm{mol} \mathrm{m} \mathrm{m}^{-2} \mathrm{~s}^{-1}$ in V100 treatment and in V0 treatment, respectively. Transpiration rate was higher in V100 treatment than in V0 treatment; stomatal conductance was significantly lower in rainfed conditions in the three species. Comparing pepper and pigweed we observed that, in drought treatment, in correspondence to the same stomatal conductance and transpiration values, in pigweed photosynthesis is nearly three times as much as pepper. Consequently, water use efficiency was higher in pigweed than in 
Table 3. Gas exchange parameters of pepper, pigweed and bindweed leaves in irrigated (V100) and not irrigated (V0) conditions.

\begin{tabular}{lccrccccccccc}
\hline & \multicolumn{3}{c}{$\mathrm{A}$} & \multicolumn{3}{c}{$\mathrm{T}$} & \multicolumn{3}{c}{ gs } & \multicolumn{3}{c}{ WUE } \\
\cline { 2 - 13 } & \multicolumn{1}{c}{ V0 } & V100 & mean & V0 & V100 & mean & V0 & V100 & mean & V0 & V100 & mean \\
\hline Pepper & $4.9 \mathrm{BC}$ & $12.0 \mathrm{BC}$ & 8.5 & 3.4 & 5.6 & $4.5 \mathrm{AB}$ & $0.07 \mathrm{C}$ & $0.26 \mathrm{~A}$ & 0.16 & 1.4 & 2.2 & $1.8 \mathrm{~B}$ \\
Pigweed & $13.9 \mathrm{~B}$ & $37.6 \mathrm{~A}$ & 25.6 & 3.9 & 7.8 & $5.8 \mathrm{~A}$ & $0.08 \mathrm{C}$ & $0.30 \mathrm{~A}$ & 0.19 & 3.5 & 4.8 & $4.2 \mathrm{~A}$ \\
Bindweed & $1.1 \mathrm{C}$ & $3.0 \mathrm{BC}$ & 2.0 & 1.7 & 4.4 & $3.1 \mathrm{~B}$ & $0.06 \mathrm{C}$ & $0.20 \mathrm{~B}$ & 0.13 & 0.7 & 0.8 & $0.7 \mathrm{~B}$ \\
mean & 6.6 & 17.5 & & $3.0 \mathrm{~B}$ & $5.9 \mathrm{~A}$ & & 0.07 & 0.25 & & 1.9 & 2.5 & \\
\hline
\end{tabular}

Values within a column followed by different letters are significantly different at $P \leq 0.01$ according to Duncan's Multiple Range Test. Number of replicates $=4$.

pepper on average, 3.5 and $1.4 \mu \mathrm{mol} / \mathrm{m} \mathrm{mol}$ $\mathrm{H}_{2} \mathrm{O}$, respectively.

The relationship between stomatal water vapour conductance and leaf water potential is also reported (Fig. 1). Our data show that stomatal conductance in all three species decreases as leaf water status achieves low values. But stomatal conductance begins first decreasing in pepper, when leaf water potential is lower than $-1.25 \mathrm{MPa}$, then in bindweed at lower than -1.0 $\mathrm{MPa}$ water potential, and only at very negative value of leaf water potential in pigweed, lower than -2.00 MPa.

From $\mathrm{A} / \mathrm{Ci}$ curves emerges that pepper and bindweed show the classic C3 plants response while pigweed has a typical $\mathrm{C} 4$ plant behaviour (Fig. 2). Examination of $A / C i$ curves indicates that $K$ (initial slope), maximum photosynthetic

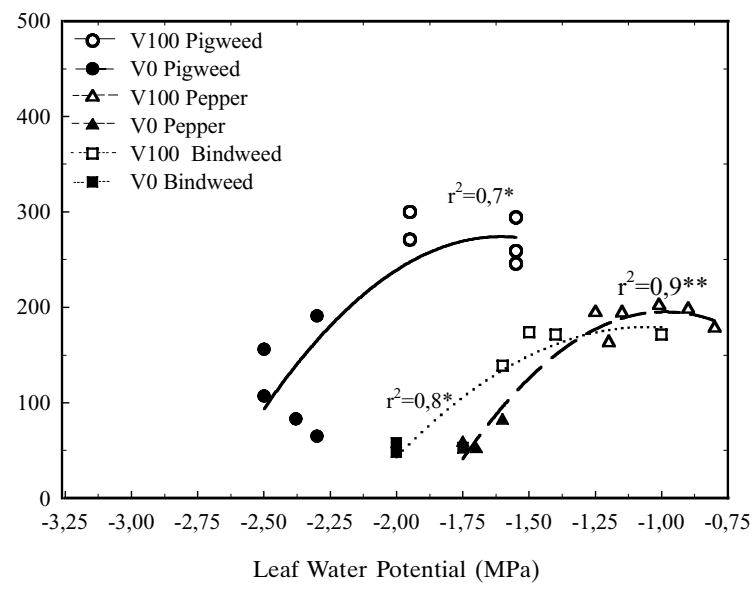

Figure 1. Stomatal water vapour conductance as a function of leaf water potential measured on pepper, pigweed and bindweed leaves in irrigated treatment (V100, open symbols, all data measured) and not irrigated treatment (V0, closed symbols, all data measured). Data were fit using non linear regression analysis. Lines are polynomial fit for all data points. rate (asymptote), and photosynthetic rate measured at atmospheric $\mathrm{CO}_{2}$ concentration were different in pepper and bindweed. Carboxylation efficiency $(\mathrm{K})$ was higher in pepper than in bindweed, $0.26 \pm 0.03$ and $0.14 \pm 0.01 \mathrm{molm}^{-2} \mathrm{~s}^{-1}$, respectively. Also, maximum photosynthetic rate (asymptote) was higher in pepper than in bindweed, as statistical analysis highlighted $(\mathrm{P}<$ $0.05)$.

In pigweed ( $\mathrm{C} 4$ plant) our data show a greater photosynthetic activity of pigweed than pepper and bindweed, as expected. PEPC activity (CE) was $0.6 \mu \mathrm{molm}^{-2} \mathrm{~s}^{-1}$, while $\mathrm{A}_{\text {sat }}$ was $84.9 \mu \mathrm{mol} \mathrm{m} \mathrm{m}^{-2} \mathrm{~s}^{-1}$, as we reported in a previous paper (Lovelli et al., 2010). Moreover our data show that, for pigweed in the Mediterranean environment, photosynthesis is not completely saturated for $\mathrm{CO}_{2}$. In fact, as figure 2 clearly shows,

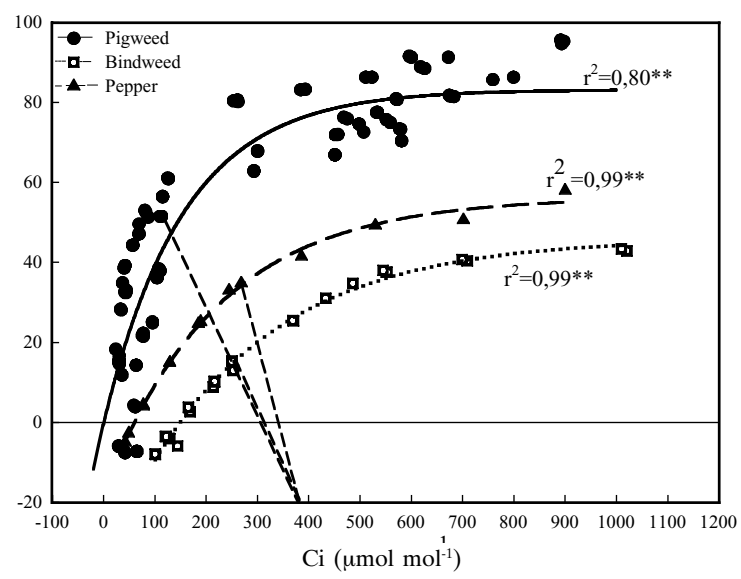

Figure 2. Response of leaf photosynthesis (measured as leaf $\mathrm{CO}_{2}$ assimilation rate, A) to a range of internal $\mathrm{CO}_{2}$ concentration $(\mathrm{Ci})$ for single leaves of pepper, pigweed and bindweed, only in irrigated plots (V100, all points obtained from four replicates). Lines are exponential fit for all data points. The dashed lines from the $\mathrm{x}$ axis indicate the $\mathrm{CO}_{2}$ assimilation rate at atmospheric $\mathrm{CO}_{2}$ concentration (operating $\mathrm{Ci}$ ). 
in pigweed the operating $\mathrm{Ci}$ of photosynthesis under ambient $\mathrm{CO}_{2}$ concentration is below the inflexion point of the $\mathrm{A} / \mathrm{Ci}$ curve.

\section{Discussion}

We observed that photosynthetic rate decreases as stomatal $\mathrm{CO}_{2}$ conductance decreases both in pepper and weeds. Our data show that stomatal conductance decreases as leaf water status achieves low values, as expected. Although there were other weeds in each plot (Tab. 1) if we compare pigweed and bindweed only, the first one significantly competes with pepper for water, since unlike bindweed, pigweed begins reducing stomatal conductance only when its leaf water potential achieves very negative values, lower than -2.00 MPa. In this sense, pigweed showed to be more drought resistant than pepper and bindweed. From a physiological point of view, both $\mathrm{C} 3$ and $\mathrm{C} 4$ species do not differ in the extent to which they resist severe drought, and the main difference in the performance as a response to drought conditions is a greater water use efficiency of the $\mathrm{C} 4$ pathway (Osmond et al., 1982). At the operating $\mathrm{Ci}$ in normal air for non-stressed plants, $\mathrm{C} 4$ species have over twice the WUE of C3 plants with an equal assimilation rate (Osmond et al., 1982; Knapp and Medina, 1999). In this way C4 plants can reach the same $\mathrm{CO}_{2}$ assimilation rate as $\mathrm{C} 3$ plants with about half the stomatal conductance, and thus half the rate of water loss (Sage and Kubien, 2003). Hence for a given amount of soil water, C4 plants can develop a larger canopy, grow more root mass and produce more seeds than their C3 competitors (Ludlow, 1985; Long, 1999). A larger leaf canopy has other effects since it can shade slower growing C3 species, while a larger root system gives to $\mathrm{C} 4$ plants the possibility to uptake soil resources before C3 competitors (Sage and Kubien, 2003).

The response of photosynthesis to intercellular $\mathrm{CO}_{2}$ is frequently used to evaluate the mechanisms controlling photosynthetic responses to environmental change, in both $\mathrm{C} 3$ and $\mathrm{C} 4$ species (Sharkey, 1985). Analysis of A/Ci response curves shows that the $\mathrm{CO}_{2}$ assimilation rate increases as ambient $\mathrm{CO}_{2}$ increases in $\mathrm{C} 3$ plants, as expected, but also in pigweed, a $\mathrm{C} 4$ plant. Actually, in the latter species the operat- ing $\mathrm{Ci}$ of photosynthesis under ambient $\mathrm{CO}_{2}$ concentration is below the inflexion point of the $\mathrm{A} / \mathrm{Ci}$ curve. Other authors (Ghannoum et al., 2000; Leakey, 2009) also concluded that in the future $\mathrm{C} 4$ photosynthesis could only be directly stimulated by elevated $\mathrm{CO}_{2}$ concentration when the operating $\mathrm{Ci}$ of photosynthesis under ambient $\mathrm{CO}_{2}$ is below the inflexion point of the $\mathrm{A} / \mathrm{Ci}$ curve. This is an important result that could affect competition and increase weed aggressiveness towards crops in agro-ecosystems. As well known, the direct physiological effects of increased atmospheric $\mathrm{CO}_{2}$ probably will be most beneficial to C3 plants (Patterson, 1995). However, the likely climatic consequences of the global warming, i.e. increased temperature and aridity, are most likely to favour C4 plants, and between them, $\mathrm{C} 4$ weeds, such as pigweed. It will be possible not only because of the wellknown $\mathrm{C} 4$ pathway superiority in drought condition but also because $\mathrm{CO}_{2}$ unsaturated weeds will remain sensitive to higher ambient $\mathrm{CO}_{2}$ levels (Sage and Kubien, 2003). Thus, when they are grown in mixed stands where competition occurs, the fast-growing $\mathrm{C} 4$ species can control the slow-growing species (Grise, 1996), especially C3 crops.

\section{Acknowledgment}

This research was funded by CLIMESCO Italian Project, contract N. 286 of 20/Feb/2006 (Ministry of University and Research).

\section{References}

Allen R.G., L.S. Pereira, D. Raes, M. Smith 1998. Crop evapotranspiration. Guidelines for computing crop water requirements. FAO Irrig. Drain. Paper N. 56, FAO, Rome, Italy.

Bajaj S., Targolli J., Liu L.F., Ho T.H.D., Wu R. 1999. Transgenic approaches to increase dehydration-stress tolerance in plants. Mol. Breed., 5:493-503.

Doorenbos J., Pruitt W.O. 1977. Crop water requirements. FAO Irrig. Drain. Paper N. 24. FAO, Rome, Italy, 144 pp.

Farquhar G.D., Sharkey T.D. 1982. Stomatal conductance and photosynthesis. Annual Review of Plant Physiology, 33:317-345.

French R.J., Schultz J.E. 1984b. Water use efficiency of wheat in a mediterranean-type environment. II. Some limitations to efficiency. Australian Journal of Agricultural Research, 35:765-775. 
Ghannoum O., von Caemmerer S., Ziska L.H., Conroy J.P. 2000. The growth response of $\mathrm{C} 4$ plants to rising atmospheric $\mathrm{CO} 2$ partial pressure: a reassessment. Plant Cell Environ., 23:931-942.

Grise D.J. 1996. Effects of elevated $\mathrm{CO}_{2}$ and high temperature on the relative growth rates and competitive interactions between a C3 (Chenopodium album) and a $\mathrm{C} 4$ (Amaranthus hybridus) annual. PhD thesis, University of Georgia, Athens, Georgia.

Hargreaves G.H., Samani Z.A. 1985. Reference Crop evapotranspiration from temperature. Applied Eng. Agric., 1:96-99.

Holm L.G., Plucknett D.L., Pancho J.V., Herberger J.P. 1977. The World's Worst Weeds: Distribution and Biology. Honolulu: University Press of Hawaii.

Horak M.J., Loughin T.M. 2000. Growth analysis of four Amaranthus species. Weed Sci., 48:347-355.

Howden S.M., Soussana J.F., Tubiello F.N., Chhetri N., Dunlop M., Meinke H. 2007. Adapting agriculture to climate change. PNAS 104, 19691-19696.

Intergovernmental Panel on Climatic Change (IPCC), 2001. In: Houghton J.T., Ding Y., Griggs D.J., Noguer M., van Der Linden P.J., Xiasou D. (eds.): The Scientific Basis. Third Assessment Report of Working Group I. Cambridge University Press, Cambridge.

Intergovernmental Panel on Climatic Change (IPCC), 2007. Fourth Assessment Report of Working Group I. Climate Change 2007: The Physical Science Basis, Summary for Policymakers.

Knapp A.K., Medina E. 1999. Success of C4 photosynthesis in the field: Lessons from communities dominated by C4 plants. In: Sage R.F., Monson R.K. (eds.): C4 Plant Biology, 251-283. Academic Press, San Diego, California.

Leakey A.D.B. 2009. Rising atmospheric carbon dioxide concentration and the future of $\mathrm{C} 4$ crops for food and fuel. Proceedings Royal Society Botany, 276:23332343. doi:10.1098/rspb.2008.1517.

Long S.P. 1999. Environmental responses. In: Sage R.F., Monson R.K. (eds.): The Biology of C4 Photosynthesis, 215-249. Academic Press, San Diego, California.

Lovelli S., Perniola M., Ferrara A., Amato M., Di Tommaso T. 2010. Photosynthetic response to water stress of pigweed (Amaranthus retroflexus L.) in a Southern-Mediterranean area. Weed Science, 58:126-131.

Ludlow M.M. 1985. Photosynthesis and dry matter pro- duction in $\mathrm{C} 3$ and $\mathrm{C} 4$ pasture plants, with special emphasis on tropical C3 legumes and grasses. Aust. J. Plant Physiol., 12:557-572.

Osmond C.B., Winter K., Ziegler H. 1982. Functional significance of different pathways of $\mathrm{CO} 2$ fixation in photosynthesis. In: Lange O.L., Nobel P.S., Osmond C.B., Ziegler H. (eds.): Encyclopedia Encyclopedia of Plant Physiology, New Series, Vol. 12B. Physiological Plant Ecology II. Water Relations and Carbon Assimilation, 479-547. Springer-Verlag, Berlin.

Patterson D.T. 1995a. Weeds in a changing climate. Weed Science, 43:685-701.

Pfirter H.A., Ammon H.U., Guntli D., Greaves M.P., De Fago G. 1997. Towards the management of field bindweed (Convolvulus arvensis) and hedge bindweed (Calystegia sepium) with fungal pathogens and cover crops. Integrated Pest Management Reviews, 2:61-69.

Sage R., Kubien D. 2003. Quo vadis C4? An ecophysiological perspective on global change and the future of C4 plants. Photosynth. Res., 77: 209-225.

Sharkey T.D. 1985. Photosynthesis in intact leaves of C3 plants. Its occurrence and a possible explanation. Botanical Review, 51:53-105.

Scholander P.F., Hammel H.T., Bradstreet E.D., Hemmingsen E.A. 1965. Sap pressure in vascular plants. Science, 148:339-346.

Tamaki G., Moffitt H.R., Turner J.E. 1975 The influence of perennial weeds on the abundance of the redbacked cutworm on asparagi. Environmental Entomology, 4:274276.

Timmons F.L. 1949. Duration of viability of bindweed seed under field conditions and experimental results in the control of bindweed seedlings. Agronomy Journal, 1949:130-133.

Tungate K.D., Israel D.W., Watson D.M., Rufty T.W. 2007. Potential changes in weed competitiveness in an agroecological system with elevated temperatures. Environ. Exp. Bot., 60:42-49.

von Caemmerer S., Furbank R.T. 1999. Modeling C4 photosynthesis. IL: R.F. Sage, R.K Monson, eds, C4 Plant Biology. Academic Press, San Diego, 173-211.

Weaver S.E., Riley W.R. 1982. The biology of Canadian weeds. 53. Convolvulus arvensis. Canadian Journal of Plant Science, 62:461-72.

Zimdahl R.L. 2004. Weed-crop competition: A review. Ames, IA: Blackwell Publishing, 27-106. 
